\title{
An Assessment of Renta Dignidad's Adequacy to Prevent Poverty in Bolivia
}

\author{
Nicole Archer \\ University of Florida
}

Faculty mentor: Cecilia Peluffo, Department of Economics

\begin{abstract}
The elderly population in developing countries is often left without access to traditional pension plans due to participation in the informal economy. To remedy this, non-contributory pension schemes are being implemented by policy makers worldwide. Bolivia, one of Latin America's poorest nations, has successfully implemented the non-contributory pension policy Renta Dignidad. Using regression discontinuity design, this paper analyzes the economic impacts of eligibility for Renta Dignidad on gender, language, and household specific subsamples of Bolivia's population. The results found indicate that eligibility for Renta Dignidad impacts households with female beneficiaries, households greater than or equal to three members, and households with beneficiaries who do not speak a native language. As the former two subsamples mentioned are more vulnerable to poverty, eligibility for Renta Dignidad is successful in its goal. However, households with native language speakers, also a population vulnerable to poverty, benefit less from eligibility for Renta Dignidad than households with non-native language speakers.
\end{abstract}

\section{Introduction}

Non-contributory pension schemes are becoming more widely utilized methods of fighting old age poverty. Unlike traditional contributory pension plans, non-contributory pension schemes allow for a sum of money to be collected each month regardless of whether the beneficiary has contributed to social-security or any other state-level pension program. Since the workforce in developing countries is largely involved in the informal economy (Blades, Ferreira, and Lugo, 2011) and thus does not contribute to any formalized pension program, noncontributory programs are often the only formalized pension plan to which many elderly people have access. Bolivia, South Africa, Mexico, Brazil, and others have implemented some form of non-contributory pension plan in order to alleviate poverty among one of the most vulnerable populations, the elderly (Barrientos, 2003). The adoption of non-contributory pension policies is endorsed by the World Bank in its multi-pillar system; the zero pillar, or non-contributory policies, is typically better suited to address the needs of the lifetime poor and the informal 
sector. The World Bank's evaluation criteria for successful pension programs include adequacy, affordability, sustainability, equitability, predictability, and robustness ("World Bank", 2008). The zero pillar ensures the adequacy of the pension system to prevent poverty in the vast majority of the elderly population ("World Bank", 2008).

This paper focuses on the case of Bolivia's non-contributory pension scheme, Renta Dignidad. Bolivia's case is particularly interesting because traditional, contributory pensions are not received by a majority of Bolivia's elderly population; it is estimated that in Bolivia, less than $23 \%$ of working age population is employed in the formal economy, while only $13 \%$ of men and $8 \%$ of women receive a contributory pension (Hernani \& Mena, 2015).

Renta Dignidad began in 1997 as a policy named Bonosol, a \$248 USD unconditional cash transfer to any citizen above the age of 65. In 2001, the payment was changed to \$120 USD, still amounting to $13 \%$ of per capita annual income (Martinez, 2004). In 2007, two laws were passed that established Renta Dignidad in its present form, which in February 2008, began to make payments to those above 60 years old. Before April 2013, Renta Dignidad awarded $\$ 340.44$ USD to any Bolivian; currently, Renta Dignidad awards \$431 USD to those who do not receive a contributory pension and $\$ 340.44$ USD to those who do. It is financed by a Direct Tax on Hydrocarbons and dividends from public companies (Escobar, Martinez, \& Mendizabal, 2013).

Previous studies on Renta Dignidad and its predecessor Bonosol use Regression Discontinuity to study the impact of the non-contributory pension scheme on economic indicators; such indicators include food and non-food consumption, household investments, and poverty levels. Martinez (2004) finds that transfers to rural households greatly effect food consumption and reduce extreme poverty levels. Escobar et al. (2013) analyze similar economic indicators via EPAM 2011, a survey conducted specifically to analyze economic outcomes of Renta Dignidad. They study Renta Dignidad's effect on rural and urban subsamples and find that Renta Dignidad is more effective at reducing poverty among urban Bolivians.

Using regression discontinuity to evaluate the EPAM 2011 survey, this paper seeks to add to existing literature by studying the estimated impact of eligibility for Renta Dignidad on vulnerable subgroups of Bolivia's population, specifically native language speakers, females, and members of large households. This is significant because in Bolivia, monolingual Spanish speakers earn, on average, $25 \%$ more than those who speak both Spanish and an indigenous language (Chiswick, Patrinos \& Hurst, 2000). Chiswick et al. (2000) also conclude that bilingual 
speakers may be penalized in the labor market because of a poorer proficiency in Spanish. Similarly, women are more likely to participate in informal or vulnerable employment and are generally paid less than men in developing countries ("Facts and Figures", 2018). Further, as stated above, only $8 \%$ of female Bolivians even receive a contributory pension (Hernani \& Mena, 2015). These factors leave the female population more vulnerable to old age poverty, as they do not have a source of income through a traditional pension scheme. Another factor that leaves households vulnerable to poverty is large household size. Larger household size is correlated with reduced earnings and reduced savings (Obreta, 2006). Thus, the elderly in larger households may be more vulnerable to old age poverty. If eligibility for Renta Dignidad is proportionately reaching Bolivia's elderly population, particularly the most at risk, then economic outcomes will improve for these population subgroups.

\section{Literature Review}

Renta Dignidad and its predecessor, Bonosol, have been evaluated for their effects on income, consumption, and poverty measures using multiple surveys and methodologies. Martinez (2004) analyzes economic effects of Bonosol on income, consumption, and investment. Martinez uses the MECOVI Encuesta de Medicion de Condiciones de Vida, a living standards measurement survey, and Encuesta Nacional de Demografia Salud, a health and demographic survey, with data from 1999-2002. Regression discontinuity is used with a cutoff point at 65 years, the age at which one is eligible to receive Bonosol. Martinez (2004) finds that in 20012002, there is an increase in per capita food consumption for beneficiary households. Household food consumption significantly increases by 82.4 Bs. (the Bolivian currency), which is equal to $97 \%$ of the payment. The effect is mostly caused by rural beneficiaries, and female beneficiaries and those with higher education levels also show increases in household food consumption in rural areas. Two consecutive payments to one household were found to have a large increasing effect on household food consumption according to Martinez. Also noteworthy, households with female beneficiaries were significantly more likely to invest in crop production, seeds, and pesticides.

Similar factors were analyzed by Hernani and Mena (2014). Hernani and Mena use household surveys from 2005-2011, along with difference-in-difference and changes-in-changes approaches, to evaluate the causal effects of Renta Dignidad on per capita consumption, per 
capita income, moderate poverty levels, and extreme poverty levels. They found no significant effects on per-capita consumption. Significant increases in per capita income were found for female beneficiary households only, and reduction in moderate poverty levels were found in neither the difference-in-difference approach nor changes-in-changes. There was, however, a significant reduction of extreme poverty in the case of female beneficiaries according to the changes-in-changes approach.

A third study of Renta Dignidad, presented by Escobar et al. (2013), is the government's official evaluation of Renta Dignidad. Escobar et al. (2013) use a sharp regression discontinuity to analyze the Encuesta a la Poblacion Adulto Mayor (EPAM 2011). EPAM 2011 is a survey that was conducted specifically to study the impact of Renta Dignidad, collecting individual and household consumption, investment, and income data (UDAPE, 2011). They find no significant impact of Renta Dignidad on per capita income for the total sample, but do find a significant 199.05 Bs. increase in per capita income for the urban population at the $10 \%$ level. Per capita consumption was found to increase by $132.29 \mathrm{Bs}$. at the $10 \%$ level for the total population, and by $237.544 \mathrm{Bs}$. at the $5 \%$ significance level for the urban population. Similarly, significant results were found for a decrease in monetary poverty. Escobar et al.'s (2013) analysis concludes that Renta Dignidad has a larger impact on Bolivia's urban population.

The papers mentioned above study subsets of Bolivia's elderly population that are more likely to experience old age poverty, such as rural and female populations. This paper seeks to add to the literature by comparing the economic effects of eligibility for Renta Dignidad on subsets of native and non-native speakers and large and small household sizes, which have not been analyzed by existing literature of which I am aware. Further, this paper analyzes economic impact of eligibility for Renta Dignidad on the female population using a different data source and estimation strategy than Hernani and Mena (2014), allowing for a comparison of results garnered by the two different methodologies.

\section{Data and Descriptive Statistics}

This paper uses data from the EPAM 2011 Survey collected by Unidad de Analisis de Politicas Sociales y Economicas (UDAPE, 2011). According to the EPAM 2011 Survey's developers, EPAM 2011 surveyed 9,158 individuals from 2,748 homes; the sampling was probalistic, two stage, and stratified by urban/rural areas and age (Escobar et al., 2013). The 
survey was conducted specifically to provide data on socioeconomic variables in homes that receive the Renta Dignidad pension. The survey has eight sections pertaining to household welfare, socio-demographic characteristics, educational background, income, non-labor income, expenses, characteristics of elderly, and health respectively. The developers of EPAM 2011 maintain that their sample was chosen such that its results are representative of 2,422,671 people living in 727,240 homes with elderly people near the age of 60 (Escobar et al., 2013).

The data is evaluated using regression discontinuity design. Thus, the household data is split into control and treated groups dependent on eligibility to receive Renta Dignidad. The treatment group consists of households whose oldest member is within the ages of [55.083, 60.083 ) years and the control group consists of households whose oldest member is within the ages of [60.083, 65.083]. This is discussed more thoroughly in the Estimation Strategy section. While EPAM 2011 surveys 2,748 homes, the total sample used in this paper contains 1448 household observations, as households that do not have a member within the ages [55.083,65.083] are not counted in this analysis. Table 1 contains the descriptive statistics for this sample.

Table 1. Descriptive Statistics

\begin{tabular}{lcc}
\hline & Control Group & Treated Group \\
\hline Female & 437 & 354 \\
& $(53.69)$ & $(55.84)$ \\
Male & 377 & 280 \\
& $(46.31)$ & $(44.16)$ \\
Native language speaker & 282 & 218 \\
& $(34.64)$ & $(34.38)$ \\
Non-native language speaker & 532 & 416 \\
& $(65.36)$ & $(65.62)$ \\
Married & 557 & 375 \\
& $(68.43)$ & $(59.15)$ \\
Unmarried & 257 & 259 \\
& $(31.57)$ & $(40.85)$ \\
No education & 143 & 153 \\
& $(17.57)$ & $(24.13)$ \\
Primary education & 401 & 312 \\
& $(49.26)$ & $(49.12)$ \\
Secondary education or higher & 270 & 169 \\
& $(33.17)$ & $(26.66)$ \\
Rural household & 421 & 304 \\
& $(51.72)$ & $(47.95)$ \\
Urban household & 393 & 330 \\
& $(48.28)$ & $(52.02)$ \\
Economically active & 672 & 451 \\
& $(82.56)$ & $(71.14)$ \\
Not economically active & 142 & 183 \\
& $(17.44)$ & $(28.86)$ \\
\hline
\end{tabular}

Note: Descriptors in the left most column refer to the oldest member of each household. The number on top represents the number of observations in the group that pertain to each descriptor, while the number in parenthesis below represents the percentage of the group that pertains to the descriptor.

Author's elaboration using EPAM 2011. 


\section{Estimation Strategy}

This paper uses regression discontinuity to evaluate the economic effects of Renta Dignidad. Regression discontinuity is a method of analysis that compares the effect of a treatment on groups just above and just below a specific cutoff. Those just under the cutoff are considered the control group, as they represent what the sample would look like without the treatment. Those just above the cutoff are considered the treated group, as their analysis compared to the control group represents the effect of the treatment on an outcome variable. It is assumed that other than the treatment, the groups near the cutoff are similar. Similar control and treated groups help establish that the differences in the observed outcome variable are due to the treatment itself (Lee \& Lemieux, 2009). This paper considers those ineligible to receive Renta Dignidad as the control group and those eligible to receive Renta Dignidad as the treated group. When using Regression discontinuity, it is important that both the assignment of the treatment is easily determined and that manipulation around the treatment is unlikely (Lee \& Lemieux, 2009). Both of these conditions are satisfied with Renta Dignidad, as the elderly are ineligible to receive payments before they reach 60 and they must show identification to receive Renta Dignidad (Escobar et al., 2013).

To determine whether a household is considered treated, a cutoff point is chosen at 60.083 years of age of the oldest member in each household; a cutoff point at 60.083 years guarantees that those considered treated are eligible to receive at least one month of payments at the time of the survey (Escobar et al., 2013). Only households with individuals within 5 years of the cutoff are considered, in order to ensure that the control and treated groups are as similar as possible (Escobar et al., 2013). Therefore, households with an elderly member within the age [55.083, 60.083) are considered the control group and households with an elderly member within the age $[60.083,65.083]$ are considered the treated group.

The following equation is used to evaluate the economic impacts of Renta Dignidad:

$$
y_{i}=\alpha+\beta_{1} D_{i}+\beta_{2}(X i-C)+\varepsilon_{i} .
$$

In equation (1), $y_{i}$ is the outcome variable and $D_{i}$ is a dichotomous variable that equals 1 when the household is in the treated group and 0 when the household is in the control group.

$X i-C$ represents the age of the oldest household member in years and months minus the cutoff age, 60.083 . 
The outcome variables observed are moderate poverty, extreme poverty, per capita income, per capita consumption, per capita food consumption, nonfood consumption, and per capita nonfood consumption. Moderate and extreme poverty are measured by comparing the per capita income of each household to the welfare threshold (UDAPE, 2011). Per capita income, per capita consumption, per capita food consumption, nonfood consumption, and per capita nonfood consumption are all measured in Bolivianos, the Bolivian currency. The data for these variables are collected in the EPAM 2011 survey and are self reported by the head of the household. If eligibility for Renta Dignidad improves economic outcomes for each subset of the population, then nonfood consumption per capita, nonfood consumption, consumption per capita, income per capita, and food consumption per capita are expected to increase, while moderate and extreme poverty levels should decrease.

The following subsets of data are analyzed: households whose oldest member is a native language speaker, households whose oldest member is a non-native language speaker, households with male oldest members, households with female oldest members, households with size less than or equal to three, and households with size greater than three. Equation (1) was used to determine the effects of Renta Dignidad on an outcome variable for each subset of data. The sample was split into subsets as they allow for a more straightforward evaluation for each subgroup considered.

\section{Results}

This section presents the estimated results found in tables 2-8 for the dichotomous variable, $D_{i}$, that represents eligibility for Renta Dignidad. This variable's coefficient denotes the effect of eligibility for Renta Dignidad on the outcome variable for individuals near the threshold of 60 years of age ${ }^{1}$. Any coefficient significant at least at the $10 \%$ level is considered statistically significant in this analysis. The following significant results were found. Non-native language speakers were impacted more by eligibility for Renta Dignidad than native language speakers. Per capita consumption significantly increased by an average of 210.97 Bs. Nonfood consumption significantly increased by 426.54 Bs., and per capita nonfood consumption significantly increased by 162.08 Bs. when eligible for Renta Dignidad. For native language speakers, only moderate poverty levels were impacted, decreasing significantly by .167 percentage points. No significant effects on extreme poverty levels are found. In Escobar et 
al.'s (2013) analysis, eligibility for Renta Dignidad is shown to have more impact on the urban population. This may explain why the strongest effects were found on non-native language speakers, as those born in rural areas are most likely to speak a native language (Chiswick et al., 2000).

Eligibility for Renta Dignidad shows no significant effect on any of the outcome variables for males. Treated females, however, show a significant decrease in moderate poverty by .126 percentage points. Per capita income increased significantly by $176.12 \mathrm{Bs}$. for the treated female group. Treated females also showed a significant increase in nonfood consumption by 489.44 Bs. and a significant increase in per capita non-food consumption by 124.34 Bs. This is congruent with the results found by Hernani and Mena (2015), who saw significant increases in per capita income and reduction of extreme poverty for females using household surveys from 2005-2011.

When household size is greater than three, per capita consumption increases significantly by 181.35 Bs. Nonfood consumption increases significantly by 691.73 Bs. and per capita nonfood consumption increases significantly by $164.85 \mathrm{Bs}$. as well. Interestingly, significant effects are not found for households with size less than or equal to three, with the exception of income per capita. As larger households often signify higher poverty rates, these results may indicate that eligibility for Renta Dignidad has stronger effects on poverty stricken households.

While regression discontinuity is helpful for determining short term differences between a control and a treated group, there are limitations to this method of analysis. According to Lee and Lemieux (2009), if the effect of the treatment is long term, then the true impact on the outcome variable may not be fully observed. Further, eligibility for treatment, determined by age, is inevitable; thus anticipation of the treatment may lead to behavioral changes that alter the outcomes (Lee and Lemieux, 2009). Another limitation of this particular study is the use of a small sample size, which may hinder more precise estimates. 
Table 2. Moderate Poverty

\begin{tabular}{lcccccc}
\hline & Female & Male & $\begin{array}{c}\text { Household } \\
\text { Size Less } \\
\text { than, equal } \\
\text { to 3 }\end{array}$ & $\begin{array}{c}\text { Household } \\
\text { Size Greater } \\
\text { than 3 }\end{array}$ & $\begin{array}{c}\text { Native } \\
\text { Language } \\
\text { Speaker }\end{array}$ & $\begin{array}{c}\text { Non-native } \\
\text { Language } \\
\text { Speaker }\end{array}$ \\
\hline Coefficient & $-0.126^{*}$ & -0.066 & -0.104 & -0.066 & $-0.167^{*}$ & -0.055 \\
Standard Error & 0.069 & 0.079 & 0.067 & 0.080 & 0.085 & 0.064 \\
$\begin{array}{l}\text { Observation } \\
\text { Size }\end{array}$ & 791 & 657 & 821 & 627 & 500 & 948 \\
$\begin{array}{l}\text { Control } \\
\text { Mean }\end{array}$ & 0.568 & 0.536 & 0.460 & 0.655 & 0.663 & 0.494 \\
$\begin{array}{l}\text { Control } \\
\text { Standard }\end{array}$ & 0.496 & 0.499 & 0.499 & 0.476 & 0.473 & 0.500 \\
\begin{tabular}{l} 
Deviation \\
\hline
\end{tabular} & & & & & & \\
\hline
\end{tabular}

Note: The coefficient represents the effect of eligibility for Renta Dignidad on incidence of moderate poverty for each subset indicated on the header row. One star denotes a coefficient significant at the $10 \%$ level and two stars denote a coefficient significant at the 5\% level. Author's elaboration using data from EPAM 2011.

Table 3. Extreme Poverty

\begin{tabular}{lcccccc}
\hline & Female & Male & $\begin{array}{c}\text { Household Size } \\
\text { Less than, } \\
\text { equal to 3 }\end{array}$ & $\begin{array}{c}\text { Household } \\
\text { Size Greater } \\
\text { than 3 }\end{array}$ & $\begin{array}{c}\text { Native } \\
\text { Language } \\
\text { Speaker }\end{array}$ & $\begin{array}{c}\text { Non-native } \\
\text { Language } \\
\text { Speaker }\end{array}$ \\
\hline Coefficient & -0.067 & -0.010 & -0.075 & 0.016 & -0.008 & -0.055 \\
Standard Error & 0.062 & 0.071 & 0.057 & 0.078 & 0.085 & 0.054 \\
$\begin{array}{l}\text { Observation } \\
\text { Size }\end{array}$ & 791 & 657 & 821 & 627 & 500 & 948 \\
$\begin{array}{l}\text { Control } \\
\text { Mean }\end{array}$ & 0.320 & 0.281 & 0.249 & 0.361 & 0.407 & 0.246 \\
$\begin{array}{l}\text { Control } \\
\text { Standard }\end{array}$ & 0.467 & 0.450 & 0.433 & 0.481 & 0.492 & 0.431 \\
\begin{tabular}{l} 
Deviation \\
\hline
\end{tabular} & & & & & & \\
\hline
\end{tabular}

Note: The coefficient represents the effect of eligibility for Renta Dignidad on incidence of extreme poverty for each subset indicated on the header row. One star denotes a coefficient significant at the $10 \%$ level and two stars denote a coefficient significant at the 5\% level. Author's elaboration using data from EPAM 2011. 
Table 4. Per Capita Income

\begin{tabular}{lcccccc}
\hline & Female & Male & $\begin{array}{c}\text { Household Size } \\
\text { Less than, } \\
\text { equal to 3 }\end{array}$ & $\begin{array}{c}\text { Household } \\
\text { Size Greater } \\
\text { than 3 }\end{array}$ & $\begin{array}{c}\text { Native } \\
\text { Language } \\
\text { speaker }\end{array}$ & $\begin{array}{c}\text { Non-native } \\
\text { Language } \\
\text { speaker }\end{array}$ \\
\hline Coefficient & $176.123^{* *}$ & 179.316 & 264.612 & 20.881 & 177.28 & 169.001 \\
Standard Error & 99.975 & 289.622 & 223.753 & 115.066 & 225.574 & 165.928 \\
$\begin{array}{l}\text { Observation } \\
\text { Size }\end{array}$ & 791 & 657 & 821 & 627 & 500 & 948 \\
$\begin{array}{l}\text { Control } \\
\text { Mean }\end{array}$ & 742.202 & 1013.298 & 1108.324 & 603.633 & 680.675 & 966.972 \\
$\begin{array}{l}\text { Control } \\
\text { Standard }\end{array}$ & 765.786 & 2255.817 & 2162.09 & 613.104 & 1869.015 & 1495.263 \\
\begin{tabular}{l} 
Deviation \\
\hline
\end{tabular} & & & & & & \\
\hline
\end{tabular}

Note: The coefficient represents the effect of eligibility for Renta Dignidad on per capita income for each household within the subset specified on the header row. One star denotes a coefficient significant at the $10 \%$ level and two stars denotes a coefficient significant at the 5\% level. Author's elaboration using data from EPAM 2011.

Table 5. Per Capita Consumption

\begin{tabular}{lcccccc}
\hline & Female & Male & $\begin{array}{c}\text { Household Size } \\
\text { Less than, Equal } \\
\text { to 3 }\end{array}$ & $\begin{array}{c}\text { Household } \\
\text { Size Greater } \\
\text { than 3 }\end{array}$ & $\begin{array}{c}\text { Native } \\
\text { Language } \\
\text { Speaker }\end{array}$ & $\begin{array}{c}\text { Non-native } \\
\text { Language } \\
\text { Speaker }\end{array}$ \\
\hline Coefficient & 149.424 & 76.787 & 37.33 & $181.352^{*}$ & -102.108 & $210.973^{* *}$ \\
Standard Error & 92.841 & 96.869 & 93.962 & 83.184 & 74.082 & 91.422 \\
$\begin{array}{l}\text { Observation } \\
\text { Size }\end{array}$ & 791 & 657 & 821 & 627 & 400 & 948 \\
& & & & & & \\
$\begin{array}{l}\text { Control } \\
\text { Mean }\end{array}$ & 751.015 & 773.959 & 929.135 & 577.744 & 596.966 & 848.932 \\
$\begin{array}{l}\text { Control } \\
\text { Standard }\end{array}$ & 572.16 & 541.673 & 642.842 & 368.174 & 488.122 & 590.303 \\
Deviation & & & & & & \\
\hline
\end{tabular}

Note: The coefficient represents the effect of eligibility for Renta Dignidad on per capita consumption for each household within the subset specified on the header row. One star denotes a coefficient significant at the $10 \%$ level and two stars denote a coefficient significant at the 5\% level. Author's elaboration using data from EPAM 2011. 
Table 6. Per Capita Food Consumption

\begin{tabular}{lcccccc}
\hline & Female & Male & $\begin{array}{c}\text { Household Size } \\
\text { Less than, } \\
\text { Equal to 3 }\end{array}$ & $\begin{array}{c}\text { Household } \\
\text { Size Greater } \\
\text { than 3 }\end{array}$ & $\begin{array}{c}\text { Native } \\
\text { Language } \\
\text { Speaker }\end{array}$ & $\begin{array}{c}\text { Non-native } \\
\text { Language } \\
\text { Speaker }\end{array}$ \\
\hline Coefficient & 25.087 & 11.043 & -3.777 & 16.505 & -55.161 & 48.894 \\
Standard Error & 48.074 & 51.788 & 50.103 & 39.033 & 52.547 & 45.054 \\
$\begin{array}{l}\text { Observation } \\
\text { Size }\end{array}$ & 791 & 657 & 821 & 627 & 500 & 948 \\
$\begin{array}{l}\text { Control } \\
\text { Mean }\end{array}$ & 487.206 & 493.503 & 588.784 & 381.797 & 422.549 & 525.941 \\
$\begin{array}{l}\text { Control } \\
\text { Standard }\end{array}$ & 331.182 & 322.630 & 367.944 & 231.443 & 317.205 & 326.838 \\
\begin{tabular}{l} 
Deviation \\
\hline
\end{tabular} & & & & & & \\
\hline
\end{tabular}

Note: The coefficient represents the effect of eligibility for Renta Dignidad on per capita food consumption for each household within the subset specified on the header row. Onestar denotes a coefficient significant at the $10 \%$ level and two stars denote a coefficient significant at the 5\% level. Author's elaboration using data from EPAM 2011.

Table 7. Nonfood Consumption

\begin{tabular}{lcccccc}
\hline & Female & Male & $\begin{array}{c}\text { Household Size } \\
\text { Less than, } \\
\text { Equal to 3 }\end{array}$ & $\begin{array}{c}\text { Household } \\
\text { Size Greater } \\
\text { than 3 }\end{array}$ & $\begin{array}{c}\text { Native } \\
\text { Language } \\
\text { Speaker }\end{array}$ & $\begin{array}{c}\text { Non-native } \\
\text { Language } \\
\text { Speaker }\end{array}$ \\
\hline Coefficient & $489.444^{* *}$ & 48.245 & $91.665^{* *}$ & $691.734^{* *}$ & -20.565 & $426.542^{*}$ \\
Standard Error & 194.322 & 159.758 & 117.282 & 275.457 & 90.191 & 196.594 \\
$\begin{array}{l}\text { Observation } \\
\text { Size }\end{array}$ & 791 & 657 & 821 & 627 & 500 & 948 \\
$\begin{array}{l}\text { Control } \\
\text { Mean }\end{array}$ & 799.756 & 687.235 & 687.235 & 1022.641 & 504.651 & 1028.638 \\
$\begin{array}{l}\text { Control } \\
\text { Standard }\end{array}$ & 769.904 & 956.827 & 956.872 & 737.221 & 469.119 & 965.062 \\
\begin{tabular}{l} 
Deviation \\
\hline
\end{tabular} & & & & & & \\
\hline
\end{tabular}

Note: The coefficient represents the effect of eligibility for Renta Dignidad on nonfood consumption for each household within the subset specified on the header row. One star denotes a coefficient significant at the $10 \%$ level and two star denotes a coefficient significant at the 5\% level. Author's elaboration using data from EPAM 2011. 
Table 8. Per Capita Nonfood Consumption

\begin{tabular}{lcccccc}
\hline & Female & Male & $\begin{array}{c}\text { Household Size } \\
\text { Less than, } \\
\text { Equal to 3 }\end{array}$ & $\begin{array}{c}\text { Household } \\
\text { Size Greater } \\
\text { than 3 }\end{array}$ & $\begin{array}{c}\text { Native } \\
\text { Language } \\
\text { Speaker }\end{array}$ & $\begin{array}{c}\text { Non-native } \\
\text { Language } \\
\text { Speaker }\end{array}$ \\
\hline Coefficient & $124.337^{*}$ & 65.383 & 41.512 & $164.848^{* *}$ & -46.946 & $162.079^{* *}$ \\
Standard Error & 62.680 & 61.738 & 61.176 & 61.210 & 33.752 & 63.561 \\
$\begin{array}{l}\text { Observation } \\
\text { Size }\end{array}$ & 791 & 657 & 821 & 627 & 500 & 948 \\
$\begin{array}{l}\text { Control } \\
\text { Mean }\end{array}$ & 263.809 & 280.457 & 340.351 & 195.947 & 174.417 & 322.991 \\
$\begin{array}{l}\text { Control } \\
\text { Standard } \\
\text { Deviation }\end{array}$ & 330.298 & 303.882 & 386.446 & 194.498 & 186.328 & 359.219 \\
\hline
\end{tabular}

Note: The coefficient represents the effect of eligibility for Renta Dignidad on per capita nonfood consumption for each household within the subset specified on the header row. One star denotes a coefficient significant at the $10 \%$ level and two stars denote acoefficient significant at the 5\% level. Author's elaboration using data from EPAM 2011.

\section{Conclusion}

Non-contributory pension plans are often used to protect the vulnerable elderly population from financial instability. In particular, they address the needs of the informal sector, as the informal sector is excluded from traditional, contributory pension schemes. Using data collected from EPAM 2011, this paper analyzes the economic impact of eligibility for Renta Dignidad, Bolivia's non-contributory pension plan, on the elderly. The results found indicate that eligibility for Renta Dignidad has the strongest impact on households with female beneficiaries, households greater than three members, and households with beneficiaries who do not speak a native language. As native language speakers are less likely to be employed in the formal labor force, these outcomes show that eligibility for Renta Dignidad is not entirely effective at reaching Bolivia's most vulnerable citizens. The results found in this analysis demonstrate that eligibility for Renta Dignidad effectively alleviates poverty measures in some subsets of its targeted demographic, and policy changes which benefit rural and non-Spanish speaking populations would increase the adequacy of the Bolivian pension system across the entire population. 


\section{Acknowledgements}

I would like to thank Dr. Knight for the guidance he has provided me throughout my undergraduate career, as well as Dr. Blair for his wisdom and encouragement to apply for the University Scholars Program among other wonderful opportunities. Lastly, I am exceedingly grateful to my faculty mentor for her guidance, including countless office hours and emails spent answering my questions and guiding me through this process.

\section{References}

Barrientos, A. (2003). What is the Impact of Non-Contributory Pensions on Poverty? Estimates from Brazil and South Africa. Chronic Poverty Research Centre Working Paper No. 33. doi:10.2139/ssrn. 1754420

Blades, D., Ferreira, F., \& Lugo, M. A. (2011). The Informal Economy in Developing Countries: An Introduction. Review of Wealth and Income, 57, S1-.S7. doi: DOI: 10.1111/j.14754991.2011.00457.x

Chiswick, B., Patrinos, A., \& Hurst, M. (2000). Indigenous Language Skills and the Labor Market in a Developing Economy: Bolivia. Economic Development and Cultural Change, 48(2), 349-367. doi:10.1086/452462

Escobar, F., Martinez, S., \& Mendizabal, J. (2013). El Impacto De La Renta Dignidad: Politica De Redistribucion Del Ingreso, Consumo, Y Reducion De La Pobreza En Hogares Con Peresonas Adultas Mayores (Bolivia, Unidad de Analisis de Politicas Sociales y Economicas). Retrieved March 20, 2018 from http://www.udape.gob.bo/evaluaciondeimpacto/12_Documento_Impacto Renta Dignidad.pdf

Facts and Figures: Economic Empowerment. (2018, July). Retrieved June 6, 2019 from http://www.unwomen.org/en/what-we-do/economic-empowerment/facts-and-figures

Hernani-Limarino, W. \& Mena, G. (2015). Understanding the Effects of Non-contributory Pension Programs. IBD Working Paper Series IBD-WP-631. http://hdl.handle.net/10419/146439

Lee, D., \& Lemieux, T. (2009). Regression Discontinuity Designs in Economics. Journal of Economic Literature, 48(2), 281-355. doi:10.3386/w14723

Martinez, S. (2004). Pensions, poverty and household investments in Bolivia (Doctoral dissertation) Berkley: University of California, Department of Economics, Oakland, CA.

Obreta, Aniceto C., Jr. (2006). "The more the poorer: why large family size causes poverty.” Policy Notes 2006-06, Philippine Institute for Development Studies (PIDS).

Unidad de Analisis de Politicas Sociales y Economicas (UDAPE). (2011). Evaluacion de Impacto de la Renta Dignidad Y Resultados de la Encuesta EPAM 2011. Retrieved from http://www.udape.gob.bo/index.php?option=com_wrapper\&view=wrapper\&Itemid=138

World Bank. (2008). The World Bank Pension Conceptual Framework. Retrieved from http:/hdl.handle.net/10986/11139 